\title{
PASABNENID
}

\section{DOLOR Y GLORIA, ¿AUTOBIOGRAFÍA, AUTOFICCIÓN O FICCIÓN AUTOBIOGRÁFICA AUDIOVISUAL?}

\author{
PAIN AND GLORY, AUTOBIOGRAPHY, AUTOFICTION OR AUDIOVISUAL
} AUTOBIOGRAPHICAL FICTION?

\author{
Agustín Gómez Gómez \\ Universidad de Málaga \\ aggomez@uma.es
}

Recibido: 11.05.2021

Aceptado: 17.09.2021

RESUMEN: Dolor y gloria (2019) de Pedro Almodóvar es una obra autorreferencial de ficción. Nuestro objetivo es establecer a qué categoría pertenece, especialmente a partir de las tres formas más frecuentes: la autobiografía, la autoficción y la ficción autobiográfica. Partimos de los postulados de Philippe Lejuene y de la teoría de la autoficción para realizar un análisis fílmico, e igualmente hemos considerado algunos textos del propio Almodóvar y entrevistas que, como paratextos, nos ayudan a comprender qué hay de personal en sus películas. También tendremos en cuenta La ley del deseo (1984) y La mala educación (2004) como dos obras anteriores con las que Dolor y gloria formaría una trilogía. A partir de La ley del deseo, en la que el autor empírico aparece en escena, dejará de tener presencia en sus obras y los autorretratos anteriores desaparecerán, pero mantendrá la representación de algunas vivencias a través de personajes delegados. En esa primera etapa encontramos autorretratos y posteriormente veremos momentos autobiográficos y autoficciones en los que algunos de sus personajes adoptan esas experiencias. El resultado de nuestro estudio es que transforma vivencias propias, cercanas y ajenas en narraciones de ficción. Las conclusiones son que no existe relato autobiográfico, en algunos casos hallamos autoficción y, principalmente, ficción autobiográfica.

PALABRAS CLAVE: Pedro Almodóvar, autobiografía, autoficción, ficción autobiográfica, autorreferencia

ABSTRACT: Pain and Glory (2019) by Pedro Almodóvar is a self-referential work of fiction. Our objective is to establish which category it belongs to, especially from the three most frequent forms: autobiography, autofiction and autobiographical fiction. We start from the postulates of Philippe Lejuene and the theory of autofiction to carry out a filmic analysis, and we have also considered some texts by 
Almodóvar himself and interviews which, as paratexts, help us to understand what is personal in his films. We will also take into account The Law of Desire (1984) and Bad Education (2004) as two previous works with which Pain and Glory would form a trilogy. From The Law of Desire, where the empirical author appears on the scene, he will no longer have a presence in his works and the previous self-portraits will disappear, but he will maintain the representation of some experiences through delegated characters. In this first stage we find self-portraits and later we will see autobiographical moments and autofictions in which some of his characters adopt those experiences. The result of our study is that it transforms own, close and of others experiences into fictional narratives. The conclusions are that there is no autobiographical account, in some cases we find autofiction and, mainly, there is autobiographical fiction.

KeYwords: Pedro Almodóvar, Autobiography, Autofiction, Autobiographical Fiction, Self-reference

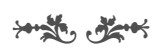

\section{INTRODUCCIÓN}

Con el estreno de Dolor y gloria (2019) los medios generalistas y divulgativos del cine se centraron principalmente en lo que de autobiográfica tiene (Smith 2019, Corona 2019). No ha sido difícil establecer referencias sobre si tal o cual escena pertenece, o puede pertenecer, a la biografía personal del director porque son muchas las entrevistas y textos en las que el propio Almodóvar ha hablado sobre él y su vida desde niño hasta hoy. El hecho de que el protagonista, Salvador Mallo (Antonio Banderas), haya adoptado una fisonomía muy parecida a la de Pedro Almodóvar, y que incluso en la promoción, con fotos y carteles, se haya utilizado la imagen del protagonista con el fondo del director, ha contribuido a identificar al autor con el protagonista. Además, Almodóvar ha introducido, en el texto y en otros paratextos, dos cuestiones que han coadyuvado en el debate respecto a la inclusión de la película como obra del yo. Se trata del concepto de autoficción, por un lado; y la idea de que existe en su obra una trilogía formada por La ley del deseo (1987), La mala educación (2004) y Dolor y gloria que funcionarían como un conjunto autobiográfico en el que el cine y el deseo son los hilos conductores, por otro.

Somos conscientes de que la heterogeneidad de formas y registros que las obras del yo audiovisual adoptan no se agota en una clasificación, más aún cuando los límites entre unas y otras son finos y permeables, pero este debate es necesario para ir fijando criterios a los que acogernos para movernos en el área audiovisual en los registros del yo.

Nuestra hipótesis es que Dolor y gloria, y buena parte de la filmografía de Almodóvar, tiene poco de autobiografía, momentos de autoficción y, posible- 
mente, mucho de novela autobiográfica. Utilizamos el término novela autobiográfica tomado de los estudios literarios, pero más adelante lo desarrollaremos como audiovisual (ficción autobiográfica).

Puesto que la última película de Pedro Almodóvar se trata de una indudable obra de ficción, el objetivo principal es dilucidar qué vinculación tiene con la vida del autor y a qué tipo de modelo autorreferencial se puede circunscribir.

Para responder a ese objetivo proponemos los siguientes interrogantes de investigación: ¿hasta dónde podemos hablar de autoficción en Dolor y gloria?; si como se ha indicado, incluso por el propio director, hay muchos elementos que se corresponden con la biografía del autor, ¿podemos hablar de autobiografía?; finalmente, ¿podría ser una ficción en la que lo ficticio parece verdadero?

\section{OBjeto de Estudio}

Como ya hemos comentado, en este artículo analizamos la última producción de Almodóvar considerando su autorreferencialidad. Nuestro propósito, por tanto, reside en dilucidar cómo se manifiesta el autor y qué hay de él en esa obra. Al mismo tiempo, ya lo señalábamos anteriormente, Dolor y gloria puede erigirse en una trilogía, o cuando menos se puede relacionar con otras de sus películas en cuanto a obra del yo. Este aspecto también lo trataremos a través de un recorrido por su producción cinematográfica en la que se pueden ver algunos signos que tienen que ver con la vida de director manchego. Esta metaficción tan frecuente en su obra, en ocasiones confundida con la autoficción, hace que determinados ítems vayan pasando de película en película y que en no pocas ocasiones se terminen confundiendo con hechos de su vida.

Hay una distinción que creemos pertinente mencionar ahora para poder avanzar en el terreno de las obras del yo en el audiovisual. Resaltamos, primero, lo de audiovisual, porque este es deudor de los estudios previos de la literatura sobre lo autorreferencial. Pero esa deuda puede problematizar su especificidad porque el lenguaje que cada una emplea es diferente, y aunque las concomitancias son permanentes, también las diferencias. De todas ellas, en las que por la lógica productiva de este estudio no podemos entrar de forma pormenorizada, nos interesa resaltar el hecho de que la mayoría de las obras cinematográficas vinculadas a esta temática autorreferencial, son documentales. ${ }^{1}$ Lo señalaba Efrén Cuevas cuando decía que "[d]e ahí que la autobiografía fílmica encuentre su hábitat natural en la práctica documental" (2005: 222). Añadía que eso no quiere decir que no existan obras de ficción autobiográficas, pero estas tienen una dimensión más amplia, como el denominado cine de autor, en el que hay reflejos autobiográficos entre el autor-director y los personajes y en la elección de los temas tratados. Por establecer un paralelismo, con múltiples matices, podríamos decir que cuando desde la literatura se habla de autobiografía podríamos aproximarnos a un documental autobiográfico, mientras que cuando se habla de novela autobiográfica estamos en el territorio de la ficción autobiográfica. Desde

${ }^{1}$ Esta cuestión fue planteada por P. Lejeune (1999: 22). 
la ficción la homonimia entre autor, personaje y narrador no tienen necesariamente que coincidir, lo que hace que los filtros y distanciamientos sean mayores y por tanto más difícil encontrar las claves autobiográficas. A esto añadimos otra cuestión relevante cuando desde la ficción este tipo de relatos autorreferenciales están interpretados por una enunciación delegada, pensemos en la clásica Otto e mezzo (Ocho y medio, 1963) de Federico Fellini interpretada por Marcello Mastroianni. En este, como en casos similares, los filtros entre el autor y el personaje hace que necesitemos de un conocimiento previo o añadido para entender lo que ese alter ego tiene de veraz.

Diferentes son los casos de Woody Allen o Nanni Moretti, ${ }^{2}$ por poner dos ejemplos también conocidos, en los que son actores de sus propias obras, y que ocuparían una "postura de autor" según la cual su identidad es reconocida por el espectador (Meizoz 2007, Casas 2017: 41). Esta presencia actoral, como veremos más adelante, se ha relacionado con un modo de autoficción, aunque adelantamos que Almodóvar, desde La ley del deseo, prefiere mantenerse fuera de plano (Gómez 2014), y hasta entonces solo tuvo pequeños papeles, nunca de protagonista, lo que lo aproxima más al modelo felliniano que al alleniano o morettiano.

A partir de la consideración de que Dolor y gloria es una película de ficción, que no encaja en el estatuto de lo que se ha venido en denominar documental, lo factual hay que buscarlo por otros derroteros. Como tendremos ocasión de comprobar, estos se encuentran fundamentalmente en paratextos y autotextos.

La sinopsis que proporciona la propia productora, y firmada por Almodóvar, señala lo siguiente:
Dolor y Gloria narra una serie de reencuentros, algunos físicos y otros recorda- dos después de décadas, de un director de cine en su ocaso. Primeros amores, segundos amores, la madre, la mortalidad, algún actor con el que el director trabajó, los sesenta, los ochenta y la actualidad. Y el vacío, el inconmensurable vacío ante la imposibilidad de seguir rodando. También habla del teatro como elemento que dinamita/dinamiza el pasado y lo arrastra hasta el presente. Ha- bla de la creación, cinematográfica y teatral, y de la imposibilidad de separar la creación de la propia vida. ${ }^{3}$

Podemos completar el argumento señalando que Salvador Mallo, un director de cine en horas bajas aquejado de múltiples problemas físicos, se reencuentra con Alberto Crespo (Asier Etxeandia), el actor de su primera película, Sabor, porque la Filmoteca ha restaurado el negativo y quiere hacer una presentación entre ambos. Ese encuentro, después de treinta y dos años, entre otras cosas, da lugar al consumo de heroína por parte de Salvador para amortiguar sus dolores físicos. Del reencuentro entre director y actor va a surgir una representación teatral en forma de monólogo, La adicción, que servirá para evocar aspectos de la infancia y de la juventud.

2 En el caso de Nanni Moretti nos referimos, naturalmente, a los casos en los que se presenta como Michelle Apicella o con otro nombre diferente al suyo, lo que solo hace en Caro diario (1993) y Aprile (1998), dos casos claros de autoficción (Herrera Zamudio 2007: 115-179).

3 <https://www.eldeseo.es/dolor-y-gloria/>. 
Del argumento se evidencia que el presente es lo relevante, y ese ocaso y dificultad para rodar lo conduce a recordar su pasado. Esos diferentes tiempos se narran mediante un montaje paralelo en el que vemos los recuerdos de infancia, que creemos flashback, pero que al final descubrimos que son el rodaje de una película, El primer deseo, lo que viene a ser la superación de todas las dificultades para seguir creando. ${ }^{4}$ Otros recuerdos, los relativos a su madre anciana (Julieta Serrano), sí se construyen a través de flashback y finalmente otros son en tiempo presente motivados por los reencuentros físicos, primero con Alberto y después con Federico (Leonardo Sbaraglia), su amor de los años ochenta. Hay un enlace entre el tiempo presente y el pasado que se traslada a El primer deseo. Se trata de una acuarela que un albañil hizo del director cuando era niño y que por casualidad encuentra en una exposición de arte popular, hecho que le sirve como catalizador para volver a escribir e incorporarlo a esa nueva película. Estamos ante una metaficción que, como una muñeca rusa, introduce dentro del relato otros relatos, literarios en el caso de La adicción convertido en monólogo teatral y cinematográficos para El primer deseo, relatado este a través de ocho flashback, a lo que sumamos otros dos para recordar el tiempo de la madre (Hernández 2021: 250).

Como hemos indicado, hay ejemplos cinematográficos notables, del que Ocho y medio es el principal. En ella, el cineasta de Rimini recurre a un alter ego para representarse a sí mismo, como un director que tiene que hacer una película "sobre la historia de un director que ya no sabía cuál era el filme que quería hacer" (Grazzini 1994: 104). Mientras encuentra la inspiración, recurre, como el propio Fellini expresó, "a los recuerdos, los sueños, las sensaciones, una maraña inextricable de cotidianidad, de memoria, de imaginación, sentimientos, hechos que sucedieron mucho tiempo antes y que conviven con aquellos que están sucediendo" (Grazzini 1994: 101). En palabras de Carmen Rodríguez, "Ocho y medio es una gran mentira, en el sentido de que no es la realidad, no se narra lo vivido, sino que es una representación de lo vivido [...] una mezcla de realidad -lo vivido-, mentira -lo recordado-, escritura onírica -lo soñado- e imaginación -lo creado" (2011: 134). La recurrencia a la infancia, las amantes y el cine como acto creativo tiene un claro paralelismo con lo que Almodóvar hará en su película y, siguiendo con la cita anterior, se verán intermitencias entre lo vivido, recordado, soñado y creado.

\section{LA AUTOBIOGRAFÍA Y SUS DERIVADOS}

Según Philippe Lejeune una autobiografía es un "relato retrospectivo en prosa que una persona real hace de su propia existencia, poniendo énfasis en su vida individual y, en particular, en la historia de su personalidad" (1994: 50); y para que se produzca -añade- deben coincidir autor, narrador y personaje $(A=N=P)$. En un paso adelante, Lejeune construye el Pacto autobiográfico, según el cual el autor se

\footnotetext{
${ }^{4}$ Un planteamiento de puesta en abismo similar ya lo desarrolló en La mala educación y lo vuelve a repetir en The Human Voice (La voz humana, 2020).
} 
compromete a decir la verdad, en un contrato simbólico entre autor y lector por el cual el autor pide al lector que le crea, lo que da lugar a un doble propósito: contar la verdad y anunciar que la va a contar. Resulta evidente que Dolor y gloria no se configura como una autobiografía, por la falta de identidad entre autor, narrador y personaje; porque no es un relato retrospectivo (fundamentalmente está contado en presente) aunque en ocasiones remita a la infancia; ni se realiza un pacto entre autor y espectador más allá de unas ciertas expectativas de marketing; ni en ningún momento Almodóvar ha señalado que se haya comprometido a decir la verdad, más bien al contrario.

Lejeune sigue buscando todos los intersticios que algo tan lábil como la autobiografía contiene y aporta otros dos conceptos, lo que denominó novela autobiográfica y pacto fantasmático, que permiten considerar a la ficción como parte de ese pacto autobiográfico. El pacto novelesco reconoce la no identidad entre autor y personaje $(A \neq P)$, lo que dirige el relato hacia la ficcionalización. Este lo define como "todos los textos de ficción en los que el lector puede tener razones para sospechar, a partir de parecidos que cree percibir, que se da una identidad entre el autor y el personaje, mientras que el autor ha preferido negar esa identidad o, al menos, no afirmarla" (1994: 63). De esta manera la veracidad o no de los hechos pasa a un segundo término, porque ahora lo que se enfatiza no es al autor sino el relato. El fantasmático da un paso adelante en tanto que el lector es invitado "a leer las novelas no solo como ficciones que remiten a una verdad sobre la 'naturaleza humana', sino también como fantasmas reveladores de un individuo" (1994: 83). Estos dos modelos, que en el caso de la literatura parecen claros, en el caso audiovisual tienen una extrapolación si consideramos al fantasmático como el conjunto de la obra del director, en nuestro caso Almodóvar, que permite a los espectadores "leer en clave autobiográfica el resto de su producción" (1994: 84), aunque sea de forma indirecta. Nos movemos, claro está, en lo que se denomina cine de autor, o al menos en el concepto de autoría que André Bazin defendió en La politique des auteurs, es decir, "el proceso analítico de elegir en la creación artística el factor personal como un criterio de referencia, y así postular su permanencia e incluso su progreso desde una obra a la siguiente" (1957: 2). Por decirlo de una forma más actualizada, cuando tiene "la responsabilidad estética de la obra" (Zumalde 2021: 274).

Esto nos permite partir de la ficción y aunque existan determinadas 'fuerzas referenciales' que nos remiten claramente al autor, estas tienen diferentes grados que pueden hacer que sean tan verosímiles como inverosímiles. El planteamiento de Lejeune nos faculta para abordar Dolor y gloria como un posible ejemplo de ficción (novela) autobiográfica $y$, al mismo tiempo, el fantasmático nos habilita para que, no solo las otras dos películas que han sido señaladas por el propio autor como tríptico autobiográfico, sino el conjunto de su obra sea considerado como revelador de la vida del director.

Lo señalado nos servirá como punto de partida para comprobar cómo se ubica la ficción en Dolor y gloria. Esto nos lleva a la otra importante y más compleja consideración: ¿es su última película una autoficción? 


\title{
3. LA AUTOFICCIÓN
}

Manuel Alberca ya señalaba que la autoficción guarda un notable parentesco con la novela autobiográfica, e incluso dudaba si era la hija o la hermana pequeña de esta (2007: 126). Estas consideraciones indican la dificultad para adscribir estas obras a uno u otro escenario. Simplificando, se puede definir la autoficción como una obra del yo en la que el autor es protagonista y que opta por un formato de ficción. La identidad del nombre (protocolo nominal) como el modo ficcional (protocolo modal) tienen una amplia nómina de variantes en las que se dilucida, en definitiva, de qué estamos hablando cuando hablamos de autoficción. Luz Elena Herrera Zamudio, respecto al nominal, que prefiere denominar "protocolo de identidad", señala tres posibilidades:

\begin{abstract}
- un autor que interpreta a un personaje con el cual comparte el nombre (homonimia completa), un derivado (homonimia por transformación), a través de citas intertextuales o porque el nombre puede establecer una equivalencia entre autor y personaje (homonimia por sustitución).

- un autor que comparte el nombre o un derivado con un personaje interpretado por otro actor.

- un autor que interpreta a un personaje de nombre diferente o anónimo. (Herrera Zamudio 2007: 54-57)
\end{abstract}

Finalmente, incluye un cuarto apartado, "homonimia cifrada", que se produce fuera del concurso nominal y que fundamentalmente se establece a partir de datos factuales, principalmente de paratextos que aportan la información suficiente para establecer la correspondencia entre autor y personaje (2007: 58-59). ${ }^{5}$

Algunos modelos están claros y otros son más sibilinos porque la naturaleza genérica no queda bien delimitada entre el relato de ficción y no ficción, o porque los filtros y distanciamientos juegan claramente al equívoco. Hay que considerar que, como señala Alberca, "la identidad nominal de personaje y autor en la autoficción constituye uno de sus pilares fundamentales y ocasiona una alteración de la expectativa del lector" (2007: 128). Para establecer una definición funcional, define la autoficción como un "relato que se presenta como ficticio, cuyo narrador y protagonista tienen el mismo nombre que el autor" (2007: 158). Como hemos visto esta característica es igual a la autobiografía. No obstante, nos indica que "la autoficción puede simular una historia autobiográfica con total transparencia y, sin embargo, tratarse de una seudoautobiografía, o por el contrario ser lo que parece sin apenas disimulo, es decir, una autobiografía en el molde de una novela". Entonces, añade, "el relato autoficticio guarda una equidistancia simétrica con respecto a la novela y a la autobiografía" (2007: 130), en lo que podríamos entender como que no es una autobiografía pues no se va a decir la verdad, aunque el autor se manifiesta, pero tampoco es una novela

\footnotetext{
${ }^{5}$ Señala al respecto, la obra de Woody Allen que no lo incluye a él como intérprete. Por ejemplo, en "Radio Days (1987) y Celebrity (1998), Seth Green y Kenneth Branagh, respectivamente, encarnan personajes construidos a partir de rasgos vinculados con la identidad de Woody Allen: origen, familia, domicilio y profesión" (2007: 58).
} 
autobiográfica porque no participa del enmascaramiento de esta. Descartada la autobiografía en Dolor y gloria, nos interesa incidir en el espacio que hay entre la autoficción y la novela (ficción) autobiográfica, pero considerando que el principal argumento de la autoficción $(A=N=P)$ no se cumple.

Alberca plantea, por tanto, dos opciones de autoficción: a) simular que una novela parezca una autobiografía sin serlo o b) camuflar un relato autobiográfico bajo la denominación de novela (2007: 129).

Si trasladamos este planteamiento al audiovisual, e insistimos en la necesidad de trasladar el término novela por película de ficción, sería autoficción cuando hay una intervención autodiegética:

- Si el autor tiene una presencia física, es decir protagonista, en un relato de ficción es autoficción; es decir, se cumple ese pilar fundamental en el que se da una identidad nominal de personaje y autor. Serían los casos en los que se simula que la ficción parece una autobiografía sin serlo (Nanni Moretti en Caro diario [1993]; Marc Recha en Días de agosto [2006] (Gómez y Parejo 2020); Elías León Siminiani en Mapa [2012]).

- Si el autor está presente y se le relaciona claramente, pero se oculta a través de un personaje. En estos casos entran los que camuflan un relato autobiográfico bajo el paraguas de la ficción (François Truffaut en La noche americana [1973]; Nanni Moretti en Palombella Rossa [1989]).

En ocasiones se han incluido obras en la autoficción sin ser autodioegéticas. Estos son los casos más problemáticos porque, aunque puedan tener rasgos que se presentan como reconocibles, eso no quiere decir que necesariamente tengan una relevancia como modo autobiográfico (Gómez y Rubio 2013: 14-15). La inspiración puede partir de experiencias personales, pero configurarse como autorreferenciales es otra cuestión. Woody Allen en su reciente autobiografía, A propósito de nada, llega a decir "[c]uando me preguntan cuál es el personaje de mis películas que más se parece a mí, solo tenéis que mirar a Cecilia en The Purple Rose of Cairo" (2020: 30). No deja de ser paradójico que sea precisamente en una película en la que él no es protagonista y que sea interpretada por una mujer. ¿Eleva esta consideración a La rosa púrpura de El Cairo (1985) como una autoficción? Sin considerar ahora la cuestión de $A=N=P$, más allá de algunas referencias que se pueden identificar con el director, nada induce a incluirla en el corpus de las autoficciones. El propio Almodóvar ha señalado en varias entrevistas a propósito de Dolor y Gloria, que parte de experiencias personales, pero que en el ejercicio de la escritura los personajes van por derroteros inesperados. Por poner otro ejemplo almodovariano, en La flor de mi secreto (1985), Leo Macías (Marisa Paredes) cuenta la anécdota de cómo con diez años leía y escribía las cartas a las vecinas analfabetas, lo que se corresponde con algo que el propio Almodóvar ha contado en algunas ocasiones (Almodóvar 2000, Gómez 2014: 75) y que vemos también en una escena de Dolor y gloria. ¿Es entonces La flor de mi secreto una autoficción? La identidad del personaje de Leo no se corresponde con la de Almodóvar, más allá de la incorporación de algunas características coincidentes puntuales, lo que tampoco certificaría esa autoficcionalización. 
Efectivamente, uno de los riesgos de la autoficción, considerada como una forma en la que participa un doble ficticio que presenta rasgos de la personalidad del autor, es que podríamos terminar considerando que toda su filmografía es autoficción. Y por lo mismo podríamos terminar concluyendo que toda obra audiovisual que tiene trazas de obra de autor podría ser autorreferencial y en algunos casos autoficciones porque sus obras tienen rasgos que les identifican.

En un texto escrito en 1990 en el Anuario de El País y recogido después en Patty Diphusa, "La promoción", Almodóvar se refiere a las hasta entonces siete películas realizadas (la última Mujeres al borde de un ataque de nervios), como obras "que hablan de mí y de mis alrededores. Todas ellas reflejan lo mejor y lo peor de mí" (Almodóvar 2011: 169). Más adelante se refiere al rechazo de determinados proyectos que le llegan porque lo que busca es tener "un espacio de dimensiones íntimas" (2011: 170). Una cita más de este relato nos lleva a ¿Qué he hecho yo para merecer esto? (1984) y la confesión de que decidió exponer "sus orígenes nada modernos, el pueblo" (2011: 171). Estas tres citas nos sirven para desvelar algo que ya sabíamos, pero que ahora resulta pertinente recordar, que su cine habla de él, pero de todas ellas solo en una hay una concreción sobre sus orígenes. En aquellos momentos, los que se corresponden con su primera etapa cinematográfica, parece que no le interesaba ni lo autobiográfico, ni sus orígenes, pero sí mostrar las experiencias vitales del presente.

\section{LA AUTOFICCIÓN ALMODOVARIANA}

En La mala educación, cuando el personaje de Ángel (Gael García), entra en el despacho de Enrique Goded (Fele Martínez) y le entrega el relato "La visita", dice algo que podríamos tomar como una autoficción: "Hay una parte inspirada en nuestra infancia y otra que no, cuando los personajes se hacen mayores y crecen. Eso ya es ficción". Los nombres de los personajes son coincidentes con el del autor (Ignacio) y con el del otro protagonista (Enrique), lo que podríamos tomar como verídico dentro de una doble ficción. Ignacio es autor, narrador y protagonista de ese relato, que se convierte en otra obra cuando es adaptada por otro autor. "La visita" comienza como un texto literario, no cinematográfico, que podríamos considerar como una obra de autoficción, pero al ser parte del relato fílmico se subsume en él y pierde su identidad de referente veraz. Esta forma de puesta en abismo en el que un texto se introduce en otro es una de las formas narrativas más utilizadas por Almodóvar. Estas reflexiones metacinematográficas y metaficcionales le permiten, entre otras cosas, trabajar como un collage con el que abre el relato y permite amplificar las lecturas. Sobre esta cuestión Vincent Colonna ha realizado una propuesta que denomina "autoficción especular", que se fundamenta en la idea de la obra dentro de la obra. Este modelo de metalepsis o puesta en abismo permite que el autor no sea el personaje principal y se mantenga en los márgenes de la obra, o incluso que sea una autoficción miniaturizada en la que solo en un determinado momento se hace presente (1989: 161-280; 2012: 103-115).

De forma parecida se introduce un relato literario en Dolor y gloria que se convierte finalmente en obra de teatro. Se trata de La adicción. El texto habla 
de la infancia de Salvador y su etapa durante los años ochenta en Madrid. En un momento le cede los derechos a Alberto Crespo para que lo interprete, pero sin que se sepa que él es el autor. Ante la perplejidad de Alberto, Salvador le confiesa "[e]s un texto confesional. No quiero que nadie me identifique" (Almodóvar 2019: 104). En la representación en la Sala Mirador, el monólogo pasa como obra de Alberto que lo narra en primera persona. Más allá de la alteración de la autoría podríamos considerarlo una obra autobiográfica, hasta el punto de que, cuando Federico la ve, reconoce perfectamente que el personaje de Marcelo es él mismo y que el autor es Salvador. El monólogo en ocasiones va acompañado de fotografías que evocan recuerdos de Costa de Marfil y La Habana, lo que proporciona referentes visualizados como reales y aporta, aún más, un aire de veracidad. No obstante, nos seguimos moviendo en el plano de la ficción, la ficción autobiográfica de Lejeune, pues nada indica que dicho relato tenga, o no, un referente extracinematográfico. Ana María Sánchez-Arce lo ha expresado correctamente cuando señala que es Salvador el que hace cine autobiográfico y autoficción, pero no Almodóvar. Este lo que viene a hacer es cine de ficción construido a partir de experiencias personales (Sánchez-Arce 2020: 292-308).

En Dolor y gloria hay un momento en el que la autoficción se convierte en protagonista. La madre le reprocha que saque a sus vecinas en sus películas, y añade "¡No me gusta la autoficción!". Ante la sorpresa de oír a su madre hablar de la autoficción, Salvador le dice: "¡Qué sabes tú de la autoficción!". Y esta le responde: "Te oí explicarlo en una entrevista" (Almodóvar 2019: 155). Antes, en una conversación con Mercedes (Nora Navas) le confiesa que no había superado la muerte de su madre y que "Cuando estoy en duermevela [...] acabo siempre pensando en mi madre y en mi infancia", a lo que Mercedes le replica: "pero nunca has hablado de ella ni de tu infancia en tus películas" (Almodóvar 2019: 151). Aquí el director manchego juega al despiste, pues es notorio que su madre está presente en muchas de sus películas. También podemos considerar que en esta respuesta la madre se refería a las vecinas, no a ella, y que cuando Salvador le dice: “¡No puedo tratarlas con más respeto ni más devoción! Cada vez que tengo ocasión hablo de ti y digo que me he formado contigo y con las vecinas, que todo os lo debo a vosotras" (Almodóvar 2019: 155). Ese hablar se refiere, dentro de la diégesis, a un comentario extracinematográfico. No deja de ser peculiar que Almodóvar, que, en tantas ocasiones ha incorporado a su madre en sus películas, tanto en persona como con actrices que la representan, en esta niegue ese protagonismo. En cualquier caso, ese "sacar" a las vecinas en sus películas dista mucho de ser una autoficción. Como hemos comentado, Almodóvar adoba la ficción con experiencias personales que le aportan un aire de veracidad, pero no por eso deja de ser ficción. Sánchez Noriega se ha referido a esa contradictoria participación del autor, que puede irrumpir de forma directa y manifiesta o "desde un yo de identificación incierta" (2017: 31).

La manera de construir determinas experiencias autorreferenciales en formato audiovisual, la podemos ver con la mediación de paratextos en unos recientes artículos publicados en la prensa por Almodóvar. En uno de ellos confiesa que el descubrimiento sexual que tuvo de niño no se produjo a través de 
la visión del albañil desnudo, como vemos en Dolor y gloria, sino con Esplendor en la hierba (1961) con Warren Beatty (Almodóvar 2020a). Esto nos lleva a la consideración de que los filtros que van desde lo personal a su conversión cinematográfica son tan grandes que estamos expuestos a perdernos, a no ser que nos den los datos para considerar esa nueva lectura. Cabría todavía añadir otra cuestión. En España la película de Elia Kazan se estrenó dos años después y muy probablemente tardase algo más en llegar a provincias. Esto quiere decir que esa revelación sexual con Beatty se produjo cuando Almodóvar tenía quince o dieciséis años, no con la edad del niño de Dolor y gloria. Por sumar más máscaras, tendríamos que considerar que en La mala educación esa iniciación sexual se produce entre Ignacio y Enrique en el cine, lo que nos proporciona una dimensión diferente. Cabría entonces preguntarnos ¿no es una transformación de lo personal en relato audiovisual sin la consideración de lo autobiográfico?

Pero en otro artículo en el mismo periódico digital, cuando escribe sus sensaciones por el confinamiento por la Covid-19, hace una declaración en la que identifica al personaje de Salvador con él mismo: "He dejado de mirar el reloj, solo lo consulto para saber cuántos pasos he caminado por el largo pasillo lateral de mi casa, el pasillo en que Julieta Serrano le reprocha a Antonio Banderas que no había sido un buen hijo, refiriéndose a mí" (Almodóvar 2020b). Lo relevante en este caso es "refiriéndose a mí", porque asume que el personaje de Salvador sería un alter ego, aunque en otras ocasiones ha expresado que ese reproche de su madre nunca tuvo lugar. El propio Almodóvar lo ha aseverado sin ninguna duda en una entrevista cuando le preguntaron si Salvador Mallo era él:

En Dolor y gloria no hay que buscar quién es quién. No es una película en clave. Es una suma de experiencias y el personaje de Antonio Banderas, al igual que los de Asier Etxeandia y Leonardo Sbaraglia, reproducen situaciones que han tenido que ver conmigo, pero que no llevan detrás nombre y apellidos. Son un poco personajes Frankenstein, seres creados a partir de otros y el resultado de haber cogido de aquí y de allá; cosas que me han ocurrido, que he oído o que estaba presente cuando pasaron. (Almodóvar 2019c)

\section{LAS AUTORREFERENCIAS Y LA FICCIÓN AUTOBIOGRÁFICA}

Lo decíamos antes, la ficción autobiográfica, se encuentra en el extremo de la autobiografía y próxima a la autoficción, pero mucho más ambigua que esta. Su uso permite una construcción narrativa mucho más libre porque no está sujeta a la veracidad y porque al incorporarse un personaje delegado del autor es mucho más elástica en el juego de parecidos y similitudes.

La obra de Almodóvar está repleta de instantes que se identifican con él, pero de una forma incierta. Esto, naturalmente, no constituye en ningún caso una autobiografía, sino que podemos reconocer momentos, en algunos casos de forma muy directa, como la presencia de su madre o la de él mismo, y en otras de un modo más velado, en las que a través de personajes de ficción podemos reconocerle. Este conocimiento viene fundamentalmente por dos vías, a través de los numerosos paratextos que en torno a él se han realizado, fun- 
damentalmente entrevistas y textos que Almodóvar ha escrito, y mediante determinadas repeticiones que a lo largo de toda su filmografía nos indican que ese mundo almodovariano está a mitad de camino entre sus experiencias y sus representaciones.

En sus seis primeras películas, las que se corresponden con el periodo de la Movida madrileña, Almodóvar interpreta en cinco de ellas un pequeño papel (no aparece en Entre tinieblas [1983]). Son autorretratos que le sirven "para reivindicarse como artista y mostrar sentimientos, experiencias, condición sexual y autoalusiones con un doble gesto exhibicionista y fabulador" (Gómez 2014: 59), en lo que podríamos adscribir como momentos de autoficción. Subrayamos momentos porque son breves apariciones, en ocasiones de pocos segundos, que no permiten hablar de un filme con un sentido autorreferencial, aunque sí de autorretratos. El ejemplo más claro lo encontramos en Laberinto de pasiones (1982). Es una escena en la que Almodóvar está dirigiendo una fotonovela con Fabio McNamara como actor y Pablo Pérez-Mínguez como fotógrafo. Cuando han terminado la sesión, Riza Niro (Imanol Arias) se dirige a Almodóvar por su nombre: "Oye, Pedro, me lo puedo llevar un minuto [refiriéndose a McNamara]". Al dirigirse a él por su nombre lo convierte en un autorretrato ortodoxo $y$, en este caso, en una escena de autoficción, en los que coinciden autor y personaje. En aquellos comienzos Almodóvar realizó numerosas actividades artísticas, entre las que hubo algunas fotonovelas, como Toda tuya y Erecciones generales, lo que además de hacer coincidir el protocolo nominal se produce también el autobiográfico. En otra escena de la misma película, hay un concierto de música en que actúan el grupo Ellos, formado por Almodóvar y McNamara, y cantan "Suck it to me", canción de Almodóvar que salió posteriormente en el disco ¡Cómo está el servicio... de señoras!

A partir de La ley del deseo Almodóvar dejará de aparecer en sus obras, pero mantendrá la representación de algunas vivencias a través de personajes delegados. La forma de trasladarlo al celuloide no se configura tampoco como autobiografías o autoficciones, sino que de nuevo volvemos a encontrar momentos en los que algunos de sus personajes adoptan esas experiencias. Si en las películas de la Movida madrileña, el director manchego se manifestaba más con el soy, a partir de Mujeres al borde de un ataque de nervios (1988) lo hará con el he sido, es decir, esta nueva visión retrospectiva lo aproxima más a instantes autobiográficos, aunque como venimos diciendo con el filtro de la ficción y con personajes delegados. De esa mirada retrospectiva hay tres reiteraciones en su filmografía vinculadas con sus orígenes que nos pueden servir para entenderlo: su madre, el río y su paso por el colegio.

Un entorno rural y su madre son dos de las referencias más utilizadas para referirse al origen de sus personajes. A su madre, Francisca Caballero, la ha integrado de dos maneras, incorporándola como actriz o a través de Chus Lampreave, primero, y con Julieta Serrano, después. Así lo expresó el propio director:

Chus desde el principio ha representado oficialmente a mi madre porque ella lo sabe y porque los tres o cuatro personajes directamente inspirados en mi 
madre los ha hecho ella. Desde luego, en La flor de mi secreto absolutamente todas las frases que ella dice las decía mi madre. (Almodóvar 2005: 480)

La idea de la inspiración es muy relevante, porque nos aleja de lo autobiográfico y nos aproxima a un modo de construir los personajes. Da igual que la vía para la creación venga de un libro, una película, una pintura, un cómic, una fotografía... o de un personaje real, porque en unos como en otros casos todo es una construcción ficcional. Volviendo a La flor de mi secreto, en Patty Diphusa tiene un relato "Botines de punta chata" (Almodóvar 2011: 110-111), que se corresponde con una escena en la que Leo (Marisa Paredes) no puede quitarse los botines que le aprietan y le ofrece a un yonki que se los quite por 1000 pesetas. Para complejizar aún más la dimensión de ese relato, en otro capítulo del mismo libro. "Ecos y esquinas" (181182), narra que fue con Rossy de Palma a París y aprovechó para comprarse unos botines que después en el hotel, una vez calzados, no se podía quitar. Él mismo señala esa coincidencia con La flor de mi secreto, así como con el relato de Patty Diphusa que acabamos de mencionar, lo que le lleva a reflexionar sobre "el eco de mis personajes en mi propia vida" (Almodóvar 2011: 182).

La primera ocasión en la que aparece su madre es en ¿Qué he hecho yo para merecer esto?, en una escena de vuelta al pueblo. Este regreso al entono rural, más emocional que referencial, se repetirá en otras películas. También es ficticio el papel de locutora de telediario que hace en Mujeres al borde de un ataque de nervios, pero no lo es en Kika. En ella hace coincidir al personaje con la persona. Doña Paquita, nombre de la presentadora, igual que el de la madre, presenta el programa de televisión Hay que leer más, en el que entrevista al escritor Nicolas Pierce (Peter Coyote). Nada más comenzar, doña Paquita le dice "cómase un choricillo, son manchegos como yo". Es un primer dato para situar geográficamente al personaje, dato coincidente con el de la madre de Almodóvar. Luego le da algunos consejos al escritor y habla de sí misma en una voluntaria declaración biográfica que afecta a su hijo:

Yo también soy viuda y no puede imaginarse la soledad lo mala que es. Los días oscurísimos, las noches largas, así que mi hijo, que dirige este programa, me ha llamado para que venga a representarlo yo y al mismo tiempo estoy con él disfrutándolo porque él no tiene tiempo de ir a verme.

A través de su madre Almodóvar nos proporciona un momento de autoficción. Es interesante, además, porque es la primera vez en la que el Almodóvar director se manifiesta de una forma veraz, aunque será como referencia indirecta a través de la voz de su madre (que la representa), y todo ello a través de la ficción.

El río también es un espacio recurrente en sus películas. En cuatro de ellas se convierte en un lugar de recuerdo placentero. Hacia el final de Todo sobre mi madre (1999), cuando Manuela (Cecilia Roth) se encuentra a Lola (Toni Cantó), enferma y con poco tiempo de vida, esta le dice que está despidiéndose de todo y quiere volver a su país para ver por última vez "el pueblo, el río y nuestra calle".

Tampoco parece ser referencial la escena del río en La mala educación. Es un momento en el que la voz off de Ignacio niño conduce el relato: 
Cada mes a los que formábamos el cuadro de honor, o sea, a los que conseguíamos las mejores notas, nos premiaban con un día entero en el campo. En esas ocasiones nos acompañaba nuestro profesor de literatura, el padre Manolo. Los días que hacía buen tiempo íbamos al río.

Es un flashback que nos muestra a los niños del colegio bañándose en el río, mientras Ignacio canta Moon river y el padre Manolo toca la guitarra. El paisaje es idílico. La cámara lenta recoge a los niños tirándose de cabeza al río o nadando con los reflejos del sol en el agua, lo que contribuye a construir una escena de placidez y goce.

En Volver (2006) el río también es relevante. Es allí donde Raimunda (Penélope Cruz) decide enterrar a su marido. Cuando vuelve toda la familia al pueblo, se desvían para ir al río. Allí recuerdan momentos de la niñez: "aquí veníamos muchas veces de merienda, ¿te acuerdas Raimunda?". Cuando madre e hija se quedan solas, Raimunda le dice: "este era el lugar preferido de tu padre [...] era lo único que echaba de menos, el río". Después vemos escrito en un árbol la inscripción "FHT 1967-2006", lo que viene a ser la lápida del difunto. La hija entiende lo que significa y exclama "me gusta que descanse aquí".

Finalmente, en Dolor y gloria, hay una escena costumbrista en el río con las mujeres lavando la ropa y cantando $A$ tu vera de Rafael de León y Juan Solano. Salvador Mallo de niño, disfruta del momento con las mujeres, viendo los peces jaboneros, las sábanas blancas tendidas sobre los juncos y oyendo como cantan en una escena que parece propia de la idealización de un lugar de la niñez que aporta seguridad y tranquilidad, de un "paraíso que inevitablemente perdemos al crecer" (Martín Garzo 2019: 220). No es por tanto un referente biográfico, sino el modo en el que va introduciendo parte de las sensaciones de su mundo familiar.

En los cuatro ejemplos citados, los personajes y las circunstancias difieren, guardando en común la evocación a un locus amoenus, que tiene como referente lejano al río Ruecas (Cañamero, Cáceres), pero claramente convertido en recuerdo bucólico.

El paso por el colegio también es algo que hemos visto en algunas de sus películas. De esa experiencia, la que ha reiterado más veces ha sido su papel como solista del coro infantil. De nuevo un paratexto nos sirve para establecer un vínculo con esa experiencia: "De niño era el solista del coro, tenía una voz blanquísima, que se quebró a los doce años. Después nada ha vuelto a ser lo mismo" (Almodóvar 2000: 22). Son tres las películas que, de diferente forma, representan escenas con el coro. En La ley del deseo Tina Quintero (Carmen Maura) entra con su hija en el Instituto Ramiro de Maeztu en el que estudió de pequeña. Al entrar escuchan la música del órgano que toca un sacerdote. Se dirige a él y le dice: "de pequeña era la solista del coro. Es lo único que echo de menos de esa época". El cura le dice que le recuerda a un antiguo alumno que cantaba en el coro. "Padre Constantino, soy yo" -le espeta Tina. "¿Tú? No puede ser". "Sí puede ser" -le responde Tina. "Has cambiado mucho" (recordemos que ahora es una mujer). "No crea, en lo esencial sigo siendo la misma" -le responde. La conversación continúa cuando le dice que "en mi vida solo hubo dos hombres, uno fue 
usted, mi director espiritual, y el otro era mi padre". El sacerdote le indica que huya de sus recuerdos como él hizo y ella zanja la conversación diciendo que no quiere olvidar, porque los recuerdos son lo único que le queda. Está claro que en esta ocasión el personaje de Tina no se corresponde con el de Almodóvar, ni siquiera con un alter ego, lo que en todo caso representaría el hermano de Tina, Pablo Quintero (Eusebio Poncela), que recordemos es un director de cine.

El traspaso de un hecho referenciado de un personaje que podríamos considerar próximo a Almodóvar a otro que no lo es, se vuelve a producir en $L a$ mala educación. Aquí es Ignacio (Ignacio Pérez) el niño cantor en el coro, mientras que Enrique es el director de cine. Ignacio es la voz principal del coro, lo que se pone de manifiesto en la escena en la que tiene que cantar en el refectorio para el padre Manolo delante de todos los sacerdotes. Podríamos considerar que existe una conexión entre La ley del deseo y esta, en el sentido que Tina manifiesta que fue, junto con su padre, el hombre más importante de su vida, dejando abierta la puerta a una interpretación de abuso por parte del sacerdote; y en La mala educación es manifiesto el maltrato del cura. También hay que recordar que, en los dos casos, cuando los personajes son adultos, hay un cambio de género, en el caso de Tina ya realizado, y en el de Ignacio en proceso.

En Dolor y gloria el desarrollo de esta escena es muy diferente. Aquí vemos que Salvador niño destaca por su voz y se convierte en el solista del coro. Las consecuencias son que lo convirtieron en un ignorante porque sin necesidad de estudiar le aprobaban todas las asignaturas, lo que no ocurre en La mala educación, donde se señala que a los que tenían mejores notas los premiaban con un día en el campo, ni tampoco hay atisbo de violencia sobre los niños.

De nuevo vemos una misma historia, ser solista del coro infantil, que se configura de tres maneras diferentes y con tres personajes que difieren entre sí.

Almodóvar se ha referido a una hipotética trilogía, en la que el protagonista es un director y en las que el deseo es motor de las acciones humanas:

Dolor y gloria es la tercera parte de una trilogía de creación espontánea que ha tardado treinta y dos años en completarse. Las dos primeras partes son $L a$ ley del deseo y La mala educación. Las tres películas están protagonizadas por personajes masculinos que son directores de cine, y en las tres el deseo y la ficción cinematográfica son los pilares de la narración. (Almodóvar 2019b: 189)

No lo dice, pero es fácil adivinar que, además, los tres directores son homosexuales, motivo por el que Los abrazos rotos, también con un director de cine como protagonista y la pasión como eje de la acción, no entra en esa lista. No es casualidad que Sabor, la primera película de Salvador Mallo, se realizase hace treinta y dos años, los mismos que distan de La ley del deseo a Dolor y gloria. En lo que nos concierne como obras autorreferenciales, tampoco encontramos muchas concomitancias para hablar de una unidad entre las tres. Pablo Quintero, Enrique Goded y Salvador Mallo son tres directores diferentes. Del primero sabemos algo de su pasado a través de su hermana, que es quien remueve los cimientos familiares; del segundo no tenemos prácticamente datos, a pesar de que vemos un trasunto de él a través de "La visita", relato que en cualquier caso queda focalizado en Ignacio y 
no tanto en él; y del tercero, del que más datos tenemos, es una visión crepuscular que se construye principalmente a través de otros relatos, la película El primer deseo y el monólogo teatral La adicción. No obstante, la presencia de la madre y algunos otros datos configuran este filme como el más autorreferencial, más allá de la veracidad de los datos, que como hemos visto son en su mayoría ficcionales.

Sin embargo, otras obras de Almodóvar van aportando referencias que se van repitiendo y proporcionan, lo que Alberca (2007: 124), refiriéndose a Pío Baroja, ha denominado autobiografismo ideológico o idiosincrásico, por el cual la forma de pensar, la filosofía vital y los resortes psicológicos hacen que el creador introduzca aspectos de su personalidad íntima, sean argumentos fundamentales o simplemente datos que dan vida a los personajes. Esto se materializa en la casi totalidad de la obra de Almodóvar, pero tiene una incidencia más clara en ¿Qué he hecho yo para merecer esto?, La ley del deseo, ¡Átame! (1989), Kika (1993), La flor de mi secreto, La mala educación, Volver y Dolor y gloria.

\section{CONCLUSIONES}

Partíamos de la hipótesis de que Dolor y gloria, y buena parte de la filmografía de Almodóvar, no es una obra autobiográfica, solo introduce algo de autoficción y como obra del yo deberíamos incluirla en la ficción autobiográfica.

Que un personaje tenga la misma profesión -director de cine- que el autor que lo ha creado es una característica fundamental para considerarlo una autobiografía. Difícilmente se podría hacer si la actividad laboral fuera otra. Igualmente, es imprescindible que exista una mirada retrospectiva para contar orígenes, familia, formación y otras vicisitudes que expliquen al personaje-autor. Aquí es donde comienzan los problemas para entender Dolor y gloria como una autobiografía. Ni existe coincidencia con los orígenes manchegos, ni emigración a Extremadura; ni Salvador Mallo tiene otros hermanos como es el caso de Pedro Almodóvar. En definitiva, lo único que encontramos es la recurrencia a un recuerdo bucólico del río y el que fuera cantante del coro infantil del colegio. Este último dato ha sido utilizado en otras dos películas de diferente manera y por otros personajes que no eran trasuntos de Almodóvar, lo que desde el punto de vista autobiográfico genera alguna que otra ambigüedad. De su juventud y madurez tampoco tenemos datos precisos, más bien anecdóticos o poco relevantes, como que hizo una primera película hace treinta y dos años, lo que no coincide con la opera prima que fue hace cuarenta años; que viajó por todo el mundo debido a sus éxitos cinematográficos; que tuvo un amor en la década de los ochenta; que tuvo algún conflicto con su madre, lo que tampoco es cierto según ha declarado en diferentes momentos; y que ya de mayor comenzaron sus problemas físicos que se fueron incrementando con los años, de los que de la larga lista que se citan en Dolor y gloria no todos son certificables si consideramos la privacidad con la que mantiene su vida personal. Casi todo lo demás que vemos en el personaje de Salvador es ficción.

Además, Dolor y gloria no se configura como una autobiografía porque no existe identidad entre autor, narrador y personaje; porque, aunque en mo- 
mentos se refiere a hechos pretéritos (infancia), no es un relato retrospectivo, sino que está contado fundamentalmente en presente; porque no se realiza un pacto entre autor y espectador más allá de unas ciertas expectativas de marketing; y porque en ningún momento Almodóvar ha señalado que se haya comprometido a decir la verdad, más bien él mismo ha dicho que los personajes reproducen situaciones con las que el director ha vivido, sin que necesariamente le hayan sucedido a él.

Quizás la cuestión que más comentarios ha generado es la relativa a la autoficción. Más allá de que en la propia película se alude a esta forma narrativa a través de la madre del protagonista, esta tiene poco recorrido. Como hemos señalado, el principal punto de partida de la autoficción es que exista una identificación nominal entre autor, personaje y narrador, lo que no se produce en esta obra. Hemos mencionado que la estructura narrativa en abismo permite introducir otros relatos que se pueden acercar a la autoficción. La inclusión del monólogo teatralizado La adicción es una autoficción diegética, es decir, lo sería como autobiografía ficcional de Salvador Mallo, no de Pedro Almodóvar, y lo mismo podríamos considerar de la otra metalepsis, la que corresponde a la construcción de El primer deseo.

Tal vez nos sirvan las propias palabras del director cuando dice "Dolor $y$ gloria no es autoficción, pero es cierto que la película parte de mí mismo" (2019a: 9), a lo que nosotros añadiríamos que los relatos pueden partir de experiencias personales, pero configurarse como autorreferenciales es otra cuestión.

La tercera opción que hemos considerado es que Dolor y gloria pueda interpretarse como una ficción autobiográfica. A diferencia de las dos anteriores, esta es más elástica, pues permite la no identidad entre autor y personaje $\left(A^{1} P\right)$. Ahora la ficcionalización predomina en el relato y el lector encuentra parecidos entre el autor y el personaje, aunque el autor no haya manifestado ese paralelismo o incluso lo haya negado. De esta manera podemos encontrar semejanzas razonables entre Salvador Mallo y Pedro Almodóvar, pero sin que exista una equivalencia entre uno y otro. Dicho de otra manera, es una indudable ficción en la que lo ficticio parece verdadero. Además, algunos de los hechos que se narran en Dolor y gloria tienen analogías con otros que hemos visto en otras obras del director, lo que induce a pensar que esas reiteraciones pueden pertenecer a experiencias personales o a vivencias conocidas, lo que permite que el conjunto de su producción cinematográfica pueda leerse en clave autorreferencial.

Lo autorreferencial no es ni necesariamente autobiográfico, ni siquiera está obligado a tener un vínculo con hechos ciertos o que hayan acontecido, pero sí que es verdad que es su marca más identificativa. Quizás por eso el modelo documental es el prioritario de las autobiografías. La autoficción, que parte de un discurso de ficción, requiere de la presencia del director, de un relato autodiegético, lo cual restringe mucho su construcción audiovisual. Es, sin embargo, en la ficción autobiográfica donde las opciones se atomizan y donde el rostro del autor tiene innumerables máscaras y un cuerpo Frankenstein. 


\section{OBRAS CITADAS}

Alberca, Manuel (2007). El pacto ambiguo. De la novela autobiográfica a la autoficción. Madrid: Biblioteca Nueva.

Allen, Woody (2020). A propósito de nada. Autobiografía. Madrid: Alianza.

Almodóvar, Pedro (2000). "Discurso del Excmo. Sr. D. Pedro Almodóvar Caballero", in Investidura como Doctor Honoris Causa por la Universidad de Castilla La Mancha del Excmo. Sr. D. Pedro Almodóvar. Ciudad Real: Universidad de Castilla La Mancha, 18-23.

Almodóvar, Pedro (2020a). "Warren Beatty, Madonna y yo", eldiario.es. <https://www.eldiario.es/tribunaabierta/Warren-Beatty-Madonna_6_1012158791.html> (1 de abril de 2020).

Almodóvar, Pedro (2020b). "El largo viaje hacia la noche", eldiario.es. <https://www.eldiario. es/tribunaabierta/largo-viaje-noche_6_1011458860.html> (30 de marzo de 2020).

Almodóvar, Pedro (2019). Dolor y gloria (guion). Barcelona: Reservoir Books.

Almodóvar, Pedro (2019a). "Prólogo", in Dolor y gloria (guion). Barcelona: Reservoir Books, 7-11.

Almodóvar, Pedro (2019b). "Memoria de las historias", in Dolor y gloria (guion). Barcelona: Reservoir Books, 189-217.

Almodóvar, Pedro (2019c). "Pedro Almodóvar nos habla de Dolor y gloria, su película más íntima", Fotogramas. <https://www.fotogramas.es/noticias-cine/a26905764/dolory-gloria-pedro-almodovar-entrevista/> (1 de septiembre de 2020).

Almodóvar, Pedro (2011). Patty Diphusa. Barcelona: Anagrama.

Almodóvar, Pedro (2005). "Epílogo", in Almodóvar: el cine como pasión. Cuenca: Universidad de Castilla La Mancha, 479-485.

Bazin, André (1957). "La politique des auteurs", Cahiers du Cinéma, 70: 2-11.

Casas, Ana (2017). "La autoficción audiovisual. Series de televisión, intermedialidad y autoconciencia paródica", in El autor a escena. Intermedialidad y autoficción, ed. Ana Casas. Madrid/Frankfurt: Iberoamericana/Vervuert, 39-58.

Corona, Alberto (2019). "Pedro Almodóvar frente al espejo: todas las referencias que hay en Dolor y gloria a la vida y las películas del director", Espinof, 6 de abril. <https:// www.espinof.com/directores-y-guionistas/pedro-almodovar-frente-al-espejo-todas-referencias-que-hay-dolor-gloria-a-vida-peliculas-director> (1 de septiembre de 2020).

Colonna, Vincent (2012). "Cuatro propuestas y tres deserciones (tipologías de la autoficción)", in La autoficción. Reflexiones teóricas, ed. Ana Casas. Madrid: Arco Libros, 85-122.

Colonna, Vincent (1989). L'autofiction (Essai sur la fictionalisation de soi en Littérature). Doctorat de l'École des Hautes Études en Sciences Sociales. París. <http://tel.archives- ouvertes.fr/docs/00/04/70/04/PDF/tel-00006609.pdf> (1 de abril de 2021).

Cuevas, Efrén (2005). "Diálogo entre el documental y la vanguardia en clave autobiográfica, in Documental y vanguardia, ed. Josetxo Cerdán y Casimiro Torreiro. Madrid: Cátedra, 219-250. 
Gómez Gómez, Agustín y Nekane Parejo (2020). "Autorretrato, retrato de familia y autoficción en Días de agosto (2005) de Marc Recha", Revista de Comunicación, 19.1: 109-123. DOI: https://doi.org/10.26441/RC19.1-2020-A7.

Gómez Gómez, Agustín (2014). "Del autorretrato a una cierta autobiografía", in El cine de Almodóvar. Una poética de lo 'trans', ed. Pedro Poyato. Sevilla: Universidad Internacional de Andalucía, 53-80.

Gómez Tarín, F. Javier y Agustín Rubio-Alcover (2013). "Narrador fílmico y autoficción. Nuevas posibilidades del punto de vista", in V Congreso Internacional Latina de Comunicación Social. La Laguna (Tenerife): Universidad de La Laguna, 1-28. <http:// www.revistalatinacs.org/13SLCS/2013_actas/033_Gomez.pdf> (1 de abril de 2021).

Grazzini, Giovanni (1994). Conversaciones con Fellini. Algún día haré una bella historia de amor. Barcelona: Gedisa.

Hernández Martínez, Eva (2021). "Atragantamiento en el cine de Pedro Almodóvar. Análisis de Dolor y Gloria", Miguel Hernández Communication Journal, 12.1: 243-266. DOI: https://doi.org/10.21134/mhcj.v12i.347.

Herrera Zamudio, Luz Elena (2007). La autoficción en el cine. Una propuesta de definición basada en el modelo analítico de Vincent Colonna. Tesis de doctorado. Madrid: Universidad Autónoma de Madrid.

Lejeune, Philippe (1999). "Ciné-moi", La faute à Rousseau. Dossier Autobiographie et cinema, 22: 22.

Lejeune, Philippe (1994). El pacto autobiográfico y otros estudios. Madrid: Megazul -Endymion.

Martín Garzo, Gustavo (2019). "Epílogo", in Dolor y gloria (guion). Barcelona: Reservoir Books, 219-223.

Meizoz, Jerôme (2007). Postures littéraires. Mises en scène modernes de l'auteur. Ginebra: Slatkine.

Rodríguez Fuentes, Carmen (2011). "Ocho y medio. Fellini, el gran mentiroso", in Solos ante la cámara, eds. Ramón Esparza y Nekane Parejo. Barcelona: Luces de Gálibo, 131138.

Sánchez-Arce, Ana María (2020). The Cinema of Pedro Almodóvar. Manchester: Manchester University Press.

Sánchez Noriega, José Luis (2017). Universo Almodóvar. Estética de la pasión de un cineasta posmoderno. Madrid: Alianza.

Smith, Paul Julian (2019). "Stardust Memories", Sight and Sound, 29.9: 34-37.

Zumalde Arregui, Imanol (2021). "Auctor in fabula. Modos y figuras de la autoalusión fílmica", Revista Signa, 30: 271-286. 